http://dx.doi.org/10.18778/1509-877X.2017.04.06

Artykuły

Anna Justyńska*

\title{
SKUTKI PRAWNOPODATKOWE WYSTĄPIENIA WSPÓLNIKA ZE SPÓŁKI OSOBOWEJ NIEBĘDĄCEJ PODATNIKIEM PODATKU DOCHODOWEGO
}

Streszczenie. Instytucja wystąpienia wspólnika ze spółki osobowej transparentnej na cele podatku dochodowego wywołuje szereg konsekwencji na gruncie prawa podatkowego, w szczególności na gruncie podatków dochodowych, a niekiedy również na gruncie podatku od towarów i usług. Skutki te różnicowane są w zależności od tego, czy wynagrodzenie występującego wspólnika wypłacane jest w pieniądzu czy też przyjmuje postać niepieniężną. Zgoła inne konsekwencje wiążą się również z przypadkiem odstąpienia od wypłacenia występującemu wspólnikowi wynagrodzenia. Przy tym kompleksowa analiza omawianej instytucji wymaga również ustalenia skutków podatkowych, jakie powstają po stronie pozostających w spółce wspólników. Celem niniejszego artykułu jest przedstawienie skutków podatkowych omawianej regulacji, z uwzględnieniem orzecznictwa sądów administracyjnych oraz interpretacji indywidualnych wydawanych przez organy podatkowe.

Słowa kluczowe: spółka osobowa, spółka niebędąca osobą prawną, wystąpienie wspólnika, podatek dochodowy, podatek od towarów i usług, wynagrodzenie w formie rzeczowej, udział kapitałowy.

1. WSTĘP

Zakończenie uczestnictwa $\mathrm{w}$ handlowej spółce osobowej nie musi każdorazowo być związane z likwidacją takiej spółki, bądź też zbyciem przysługującego wspólnikowi ogółu praw i obowiązków w spółce na rzecz

* Doradca podatkowy, doktorantka w Katedrze Prawa Podatkowego Wydziału Prawa i Administracji Uniwersytetu Łódzkiego, e-mail: a.justynska@interia.pl 
podmiotu trzeciego, na podstawie art. $10 \$ 1$ Kodeksu spółek handlowych ${ }^{1}$. Zmiana składu osobowego handlowej spółki osobowej może zostać również dokonana poprzez złożenie przez jednego ze wspólników oświadczenia o wypowiedzeniu umowy spółki, na podstawie art. $61 \S 1$ k.s.h. W takim wypadku, jeżeli pozostający w spółce wspólnicy postanowią o dalszym trwaniu spółki, występujący wspólnik ma prawo do wynagrodzenia $\mathrm{z}$ tytułu jego wystąpienia ze spółki.

Zdarzenie to niesie ze sobą daleko idące konsekwencje na gruncie ustaw podatkowych nie tylko w odniesieniu do występującego wspólnika, ale również w odniesieniu do wspólników pozostających w spółce. W niniejszym opracowaniu przedstawiono rozważania na temat skutków prawnych i podatkowych czynności wystąpienia wspólnika ze spółki osobowej transparentnej na cele podatku dochodowego (jawnej, partnerskiej oraz komandytowej) za wypłatą wynagrodzenia w formie pieniężnej lub rzeczowej, z jednoczesnym uwzględnieniem przypadku, gdy wystąpienie ze spółki następuje bez wypłaty wynagrodzenia wspólnikowi występującemu. Rozważania te zostały uzupełnione analizą skutków podatkowych powstających po stronie pozostających w spółce wspólników w związku z wystąpieniem jednego $\mathrm{z}$ nich.

\section{INSTYTUCJA WYSTĄPIENIA WSPÓLNIKA ZE SPÓŁKI OSOBOWEJ}

Wypowiedzenie umowy spółki na podstawie art. $61 \S 1$ k.s.h. dla swej skuteczności wymaga jedynie woli wspólnika składającego oświadczenie o wypowiedzeniu umowy spółki, bez konieczności uzyskania zgody pozostałych wspólników czy samej spółki. Stosownie do treści powołanego powyżej przepisu, jeżeli spółkę zawarto na czas nieoznaczony, wspólnik może wypowiedzieć umowę spółki na sześć miesięcy przed końcem roku obrotowego. Jednocześnie, zgodnie z art. $61 \S 3$ k.s.h. „wypowiedzenia dokonuje się $\mathrm{w}$ formie pisemnego oświadczenia, które należy złożyć pozostałym wspólnikom albo wspólnikowi uprawnionemu do reprezentowania spółki”. Wspólnicy w umowie spółki w dowolny sposób mogą ustalić termin, w jakim oświadczenie o wypowiedzeniu umowy spółki może zostać dokonane. Nie jest natomiast możliwe wyłączenie prawa wspólnika do wypowiedzenia

${ }^{1}$ Ustawa z dnia 15 września 2000 roku - Kodeks spółek handlowych, Dz.U. z 2017 r., poz. 1577 ze zm.; dalej: k.s.h. 
umowy spółki². Jednocześnie, nie ma on obowiązku przedstawienia uzasadnienia dla złożenia oświadczenia o wypowiedzeniu umowy spółki, lecz również nie ma prawa do uzależnienia wypowiedzenia umowy spółki od uprzedniego spełnienia się warunku. Wypowiedzenie umowy spółki pod warunkiem jest bowiem nieważne ${ }^{3}$.

Co do zasady wypowiedzenie umowy spółki jest jedną z przyczyn rozwiązania umowy spółki i pociąga za sobą obowiązek wszczęcia procesu likwidacji. Niemniej stosownie do treści art. $64 \$ 1$ k.s.h. pomimo wypowiedzenia umowy spółki przez wspólnika spółka trwa nadal pomiędzy pozostałymi wspólnikami, jeżeli umowa spółki tak stanowi lub pozostali wspólnicy tak postanowią.

Zasady określania wysokości wynagrodzenia wspólnikowi występującemu ze spółki zostały określone w art. 65 k.s.h. Stosownie do $\$ 1$ powoływanego przepisu „w przypadku wystąpienia wspólnika ze spółki wartość udziału kapitałowego wspólnika albo jego spadkobiercy oznacza się na podstawie osobnego bilansu, uwzględniającego wartość zbywczą majątku spółki”. Przepis ten odnosi się do pojęcia „udziału kapitałowego”, który stosownie do treści art. $50 \$ 2$ k.s.h. odpowiada wartości rzeczywiście wniesionego przez wspólnika wkładu.

W przypadku wypowiedzenia umowy spółki dniem bilansowym, na który powinien zostać przygotowany bilans, o którym mowa w art. 65 $\$ 1$ k.s.h., jest ostatni dzień roku obrotowego, w którym upłynął termin wypowiedzenia. Wartość udziału kapitałowego, obliczonego z uwzględnieniem powyższych reguł, powinna zostać wypłacona występującemu wspólnikowi w pieniądzu, a jedynie rzeczy wniesione przez niego tylko do używania powinny zostać zwrócone w naturze (art. $65 \$ 3$ k.s.h.). Zaznaczyć należy, że jeżeli udział kapitałowy występującego wspólnika, obliczony według powyższych zasad, wykazuje wartość ujemną, to wspólnik zobowiązany będzie do wyrównania spółce brakującej, przypadającej na niego wartości. Rozszerzenie wynikającego z umowy spółki zwolnienia z partycypacji w stratach bieżących w doktrynie przyjmuje się za wątpliwe 4 . Tym samym, zasadne jest wyraźne wskazanie w umowie spółki zwolnienia wspólnika z obowiązku wyrównania brakującej wartości udziału kapitałowego przypadającego na występującego ze spółki wspólnika.

${ }^{2}$ M. Rodzynkiewicz, Kodeks spółek handlowych. Komentarz, wyd. 4, Warszawa 2012, s. 121.

${ }^{3}$ Wyrok Sądu Najwyższego z 29 kwietnia 2009 r., sygn. II CSK 614/08.

${ }^{4}$ Por. M. Rodzynkiewicz, op. cit., s. 126. 
Oprócz obowiązku zwrotu występującemu wspólnikowi przypadającego na niego udziału kapitałowego oraz zwrotu rzeczy wniesionych tylko do używania, występujący wspólnik ma ponadto prawo do żądania wypłaty przypadającego na niego udziału w zysku za poprzednie lata obrotowe oraz za rok, w którym złożył oświadczenie o wypowiedzeniu umowy spółki. Ponadto, zgodnie z art. $65 \$ 5$ k.s.h. występujący wspólnik ma również prawo do uczestnictwa w zysku ze spraw jeszcze niezakończonych. Uprawnienie to obarczone jest jednak ryzykiem, bowiem wspólnik ten uczestniczy również w ewentualnej stracie ze spraw jeszcze niezakończonych, a jednocześnie nie ma już wpływu na prowadzenie tych spraw.

Wspólnicy w umowie spółki mają prawo do określenia innych zasad ustalania wynagrodzenia $\mathrm{z}$ tytułu wystąpienia wspólnika ze spółki, a nawet do wyłączenia prawa do wynagrodzenia za wystąpienie ze spółki. Nie ma tym samym przeszkód, aby wspólnikowi przysługiwało prawo do zwrotu wniesionego przez niego wkładu niepieniężnego, w miarę możliwości w tej samej formie, w której został on wniesiony (np. zwrotu wniesionej nieruchomości).

\section{WYSTĄPIENIE WSPÓLNIKA ZE SPÓ£KI OSOBOWEJ}

- SKUTKI NA GRUNCIE USTAW PODATKOWYCH

\subsection{Wystąpienie za wynagrodzeniem w formie pieniężnej}

Otrzymanie przez występującego wspólnika środków pieniężnych tytułem wynagrodzenia za wystąpienie ze spółki niebędącej osobą prawną (tj. ze spółki jawnej, partnerskiej lub komandytowej) pozostaje neutralne podatkowo na gruncie podatku od czynności cywilnoprawnych czy podatku od towarów i usług, lecz wywołuje skutki na gruncie ustaw o podatkach dochodowych.

W pierwszej kolejności wskazać należy, że stosownie do treści art. 14 ust. 2 pkt 16 ustawy z dnia 26 lipca 1991 r. o podatku dochodowym od osób fizycznych ${ }^{5}$, do przychodów z pozarolniczej działalności gospodarczej zalicza się środki pieniężne otrzymane przez wspólnika spółki niebędącej osobą prawną z tytułu wystąpienia z takiej spółki. Jednocześnie, zgodnie z art. 14 ust. 3 pkt 11 u.p.d.o.f., do przychodów podlegających opodatkowaniu podatkiem dochodowym nie zalicza się środków pieniężnych

${ }^{5}$ Ustawa z dnia 26 lipca 1991 r. o podatku dochodowym od osób fizycznych, Dz.U. z 2018 r., poz. 200 ze zm.; dalej: u.p.d.o.f. 
otrzymanych przez wspólnika spółki niebędącej osobą prawną z tytułu wystąpienia z takiej spółki, w części odpowiadającej uzyskanej przed wystąpieniem przez wspólnika nadwyżce przychodów nad kosztami ich uzyskania, o których mowa w art. 8, pomniejszonej o wypłaty dokonane z tytułu udziału w tej spółce i wydatki niestanowiące kosztów uzyskania przychodów.

Oznacza to, że w pierwszej kolejności należy obliczyć różnicę pomiędzy przychodami i kosztami ich uzyskania, przypadającymi występującemu wspólnikowi w całym okresie, w którym był on wspólnikiem spółki, z której występuje. Wartość tę należy ustalić przy uwzględnieniu ogólnych zasad dotyczących ustalania dochodu z tytułu uczestnictwa w spółce niebędącej osobą prawną, wynikających z art. 8 u.p.d.o.f. Następnie kwotę tę należy pomniejszyć o wypłacone występującemu wspólnikowi środki z tytułu udziału w spółce, a także o poniesione wydatki niestanowiące kosztów uzyskania przychodów. Tak obliczona wartość nie zostanie zaliczona do przychodów, nadwyżka natomiast stanowić będzie podstawę do ustalenia dochodu do opodatkowania $\mathrm{z}$ tytułu otrzymania wynagrodzenia za wystąpienie ze spółki niebędącej osobą prawną. Stosownie do treści art. 24 ust. $3 c$ u.p.d.o.f., „dochodem z tytułu wystąpienia wspólnika ze spółki niebędącej osobą prawną w przypadku otrzymania środków pieniężnych jest różnica między przychodem $\mathrm{z}$ tego tytułu, ustalonym zgodnie $\mathrm{z}$ art. 14, a wydatkami na nabycie lub objęcie prawa do udziałów w takiej spółce”. Od tak obliczonego dochodu podatnik zobowiązany będzie odprowadzić zaliczkę na poczet podatku dochodowego, a następnie wykazać go w rocznym zeznaniu podatkowym ${ }^{6}$.

W podobny sposób uregulowane zostały zasady opodatkowania środków pieniężnych wypłacanych występującemu wspólnikowi spółki niebędącej osobą prawną, będącemu podatnikiem podatku dochodowego od osób prawnych. Stosownie do art. 12 ust. 4 pkt 3a lit. b ustawy z dnia 15 lutego 1992 r. o podatku dochodowym od osób prawnych ${ }^{7}$, do przychodów opodatkowanych podatkiem dochodowym nie zalicza się środków pieniężnych otrzymanych przez wspólnika spółki niebędącej osobą prawną z tytułu wystąpienia z takiej spółki, w części odpowiadającej wydatkom na nabycie lub objęcie prawa do udziałów w takiej spółce i uzyskanej przed

${ }^{6}$ Por.: interpretacja indywidualna Dyrektora Izby Skarbowej w Bydgoszczy z 16 kwietnia 2014 r., nr ITPB1/415-54/14/MP.

${ }^{7}$ Ustawa z dnia 15 lutego 1992 r. o podatku dochodowym od osób prawnych, Dz.U. z 2018 r., poz. 1036 ze zm.; dalej: u.p.d.o.p. 
wystąpieniem przez wspólnika nadwyżce przychodów nad kosztami ich uzyskania, o których mowa w art. 5, pomniejszonej o wypłaty dokonane z tytułu udziału w takiej spółce i wydatki niestanowiące kosztów uzyskania przychodów.

W praktyce wątpliwości budzić może, co należy rozumieć pod pojęciem wydatków na nabycie lub objęcie prawa do udziałów w spółce niebędącej osobą prawną, o których mowa w art. 12 ust. 4 pkt 3a lit. b u.p.d.o.p. oraz w art. 24 ust. 3c u.p.d.o.f. Jeżeli występujący wspólnik wniósł do spółki, z której występuje, wkład pieniężny, to jego wartość stanowić będzie wartość wydatków na objęcie prawa do udziałów w spółce niebędącej osobą prawną, o której mowa w powołanych powyżej przepisach ${ }^{8}$. Podobnie, jeżeli ogół praw i obowiązków w spółce niebędącej osobą prawną został nabyty tytułem umowy sprzedaży, wydatkami na nabycie udziałów w spółce będzie cena sprzedaży uiszczona przez występującego wspólnika.

Jednocześnie podkreślić należy, że obliczenie dochodu do opodatkowania następuje w oderwaniu od kodeksowych zasad ustalania wysokości wynagrodzenia przysługującego wspólnikowi wypowiadającemu umowę spółki, czyli w oderwaniu od zasad ustalania wartości udziału kapitałowego do wypłaty wspólnikowi. Dlatego też, jeżeli występujący wspólnik nabył ogół praw i obowiązków tytułem darowizny, pomimo że przysługuje mu udział kapitałowy w spółce o określonej wartości, to faktycznie nie poniósł on żadnych wydatków na nabycie ogółu praw i obowiązków w spółce, przez co nie będzie możliwe pomniejszenie osiągniętego przez niego przychodu (dochodu) z tytułu otrzymania wynagrodzenia za wystąpienie ze spółki. Ten sam skutek odnosić się będzie również do innych przypadków nieodpłatnego nabycia ogółu praw i obowiązków w spółce niebędącej osobą prawną przez wspólnika będącego podatnikiem podatku dochodowego od osób prawnych.

Wątpliwości powstają również w przypadku, gdy występujący wspólnik wniósł do spółki wkład niepieniężny. Zgodnie ze stanowiskiem organów podatkowych, pod pojęciem wydatków na objęcie udziałów w spółce niebędącej osobą prawną, o których mowa w art. 24 ust. $3 c$ u.p.d.o.f. oraz w art. 12 ust. 4 pkt 3a lit. b u.p.d.o.p., należy rozumieć tzw. „wydatki historyczne”, czyli wydatki, które zostały poniesione przez występującego wspólnika na wytworzenie lub nabycie przedmiotu wkładu (np. cena sprzedaży,

${ }^{8}$ Por.: interpretacja indywidualna Dyrektora Izby Skarbowej w Warszawie z 16 lutego 2017 r., nr 1462-IPPB1.4511.1193.2016.2.MJ. 
uiszczona przez występującego wspólnika), a nie wartość rynkową składnika majątku, który został przez występującego wspólnika wniesiony do spółki tytułem wkładu niepieniężnego. Ponadto, jednym z dalszych warunków jest to, aby poniesione wydatki historyczne nie zostały uprzednio zaliczone do kosztów uzyskania przychodów, np. w formie odpisów amortyzacyjnych ${ }^{9}$. Stanowisko to potwierdzane jest w orzeczeniach sądów administracyjnych ${ }^{10}$. Należy jednak zwrócić uwagę na pogląd odrębny od powyższego, zgodnie z którym w przypadku wystąpienia wspólnika ze spółki niebędącej osobą prawną, za wydatki na objęcie udziałów w tej spółce należy uznać wartość wnoszonego do spółki aportu określoną na dzień wniesienia go do spółki na podstawie raportu niezależnego rzeczoznawcy ${ }^{11}$.

Powyższe zasady określania wysokości wydatków na nabycie lub objęcie udziałów w spółce niebędącej osobą prawną znajdą zastosowanie również w przypadku, gdy spółka, z której występuje wspólnik, powstała w wyniku przekształcenia innej spółki. Przykładowo, w przypadku wystąpienia ze spółki komandytowej, powstałej w wyniku przekształcenia spółki cywilnej, za wydatki na objęcie udziałów w spółce komandytowej, o których mowa w art. 24 ust. 3c u.p.d.o.f. oraz w art. 12 ust. 4 pkt $3 a$ lit. b u.p.d.o.p., uznana zostanie wartość wkładu pieniężnego wniesionego do spółki przekształconej (spółki cywilnej) ${ }^{12}$.

${ }^{9}$ Interpretacja indywidualna Dyrektora Izby Skarbowej w Bydgoszczy z 8 maja 2015 r., nr ITPB3/4510-133/15/AW; interpretacja indywidualna Dyrektora Izby Skarbowej w Bydgoszczy z 12 grudnia 2016 r., nr 0461-ITPB1.4511.800.2016.1.DP; interpretacja indywidualna Dyrektora Krajowej Informacji Skarbowej z 20 czerwca 2017 r., nr 0113-KDIPT2-3.4011.12.2017.3.AC; interpretacja indywidualna Dyrektora Izby Skarbowej w Warszawie z 15 stycznia 2015 r., nr IPPB1/415-1202/14-2/MS1.

${ }^{10}$ Wyrok Wojewódzkiego Sądu Administracyjnego w Warszawie z 10 maja 2016 r., sygn. III SA/Wa 1325/15 [prawomocny]; wyrok Wojewódzkiego Sądu Administracyjnego w Bydgoszczy z 18 sierpnia 2015 r., sygn. I SA/Bd 474/15 [prawomocny]; wyrok Wojewódzkiego Sądu Administracyjnego w Krakowie z 4 lipca 2012 r., sygn. I SA/Kr 672/12 [prawomocny].

${ }^{11}$ Wyrok Wojewódzkiego Sądu Administracyjnego w Łodzi z 5 lipca 2018 r., sygn. III SA/Wa 1325/15 [nieprawomocny]; wyrok Wojewódzkiego Sądu Administracyjnego w Łodzi z 14 grudnia 2017 r., sygn. I SA/Łd 903/17 [nieprawomocny]; wyrok Wojewódzkiego Sądu Administracyjnego w Białymstoku z 11 maja 2016 r., sygn. I SA/Bk 1362/15 [nieprawomocny]; wyrok Naczelnego Sądu Administracyjnego z 24 listopada 2015 r., sygn. II FSK 2224/13.

12 Por.: interpretacja indywidualna Dyrektora Izby Skarbowej w Warszawie z 11 lipca 2016 r., nr IPPB1/4511-504/16-2/ES. 
Gdy występującym wspólnikiem jest spółka niebędąca osobą prawną, transparentna, opodatkowanie na cele podatku dochodowego wynagrodzenia otrzymywanego przez tę spółkę z tytułu wystąpienia $\mathrm{z}$ innej spółki niebędącej osobą prawną będzie następować na podstawie przepisów ustawy o podatku dochodowym od osób fizycznych (jeżeli wspólnikami występującej spółki są podatnicy podatku dochodowego od osób fizycznych) lub na podstawie przepisów ustawy o podatku dochodowym od osób prawnych (jeżeli wspólnikami występującej spółki są podatnicy podatku dochodowego od osób prawnych). Opodatkowanie następuje stosownie do udziału w zysku przysługującego każdemu ze wspólników występującej spółki niebędącej osobą prawną, stosownie do zasad wynikających $\mathrm{z}$ art. 8 u.p.d.o.f. oraz art. 5 u.p.d.o.p. Dotyczy to również przypadku, gdy wspólnikami w występującej spółce niebędącej osobą prawną są zarówno podatnicy podatku dochodowego od osób fizycznych, jak i podatnicy podatku dochodowego od osób prawnych.

Jeżeli występujący ze spółki niebędącej osobą prawną wspólnik otrzymał tytułem wynagrodzenia środki pieniężne w kwocie przewyższającej wartość, o której mowa w art. 14 ust. 3 pkt 12 u.p.d.o.f. oraz w art. 12 ust. 4 pkt 3 a lit. b u.p.d.o.p., po jego stronie powstaje przychód do opodatkowania podatkiem dochodowym. Jeżeli występującym wspólnikiem jest podatnik podatku dochodowego od osób fizycznych, przychód ten należy zaliczyć do źródła, o którym mowa w art. 10 ust. 1 pkt 3 u.p.d.o.f., tzn. do przychodów z pozarolniczej działalności gospodarczej ${ }^{13}$. W przypadku występujących wspólników będących podatnikami podatku dochodowego od osób prawnych, gdzie przychodem jest nadwyżka ponad wartość wskazaną w art. 12 ust. 4 pkt 3a lit. b u.p.d.o.p., począwszy od 1 stycznia 2018 r. również konieczne jest uprzednie dokonanie prawidłowej kwalifikacji wskazanego przychodu do jednego z dwóch źródeł przychodów. Od 1 stycznia 2018 r. w podatku dochodowym od osób prawnych wprowadzony został podział na przychody z zysków kapitałowych oraz pozostałe przychody, mający zastosowanie również do przychodów osiąganych za pośrednictwem spółki niebędącej osobą prawną. Przychód z tytułu otrzymania wynagrodzenia za wystąpienie ze spółki niebędącej osobą prawną nie stanowi przychodu z zysków kapitałowych, o których mowa w art. 7b u.p.d.o.p., lecz zostanie zaliczony do pozostałych źródeł przychodów.

${ }^{13}$ Por.: interpretacja indywidualna Dyrektora Izby Skarbowej w Łodzi z 12 lipca 2016 r., nr 1061-IPTPB1.4511.418.2016.1.RK. 
Jeżeli wypłata wynagrodzenia występującemu wspólnikowi następować będzie w ratach (np. miesięcznych), a nie jednorazowo, przychód powstawać będzie każdorazowo z momentem otrzymania części wynagrodzenia ${ }^{14}$.

Na zakończenie podkreślić jeszcze raz należy, że powyżej opisane przepisy prawa dotyczą zasad opodatkowania otrzymania wynagrodzenia za wystąpienie ze spółki osobowej niebędącej podatnikiem podatku dochodowego, tj. spółki jawnej, spółki partnerskiej oraz spółki komandytowej, a także wynagrodzenia za wystąpienie ze spółki cywilnej (zaliczanej na gruncie ustaw o podatkach dochodowych do spółek niebędących osobami prawnymi). Nie dotyczą zatem zasad opodatkowania wynagrodzenia otrzymanego przez komplementariusza spółki komandytowo-akcyjnej z tytułu wystąpienia $\mathrm{z}$ tej spółki. Stosownie do treści art. 7b ust. 1 pkt 1 lit. c u.p.d.o.p. oraz art. 24 ust. 5 pkt 1 b u.p.d.o.f., wynagrodzenie to stanowi przychód odpowiednio z zysków kapitałowych (podatek dochodowy od osób prawnych) lub przychód z udziału w zyskach osób prawnych (podatek dochodowy od osób fizycznych).

3.2. Wystąpienie za wynagrodzeniem w formie rzeczowej - skutki na gruncie podatku dochodowego

Jeżeli wspólnikowi występującemu ze spółki niebędącej osobą prawną tytułem wynagrodzenia przyznano zamiast środków pieniężnych składniki niepieniężne, stosownie do treści art. 14 ust. 3 pkt 12 lit. b u.p.d.o.f. oraz art. 12 ust. 4 pkt 3 b u.p.d.o.p. ich wartość nie jest zaliczana do przychodów opodatkowanych podatkiem dochodowym w momencie ich otrzymania. Przepisy powyższe dotyczą wszystkich składników majątku niespełniających definicji „środków pieniężnych” na gruncie ustaw o podatkach dochodowych. Zgodnie $z$ art. 12 ust. 4 g u.p.d.o.p. oraz art. 14 ust. 8 u.p.d.o.f., przez środki pieniężne rozumie się również wartość wierzytelności uprzednio zarachowanej jako przychód należny, pomniejszonej o należny podatek od towarów i usług, oraz wierzytelności z tytułu udzielonej przez spółkę niebędącą osobą prawną pożyczki - z wyjątkiem wierzytelności z tytułu odsetek od opóźnionej zapłaty oraz wierzytelności z tytułu odsetek od takiej pożyczki,

${ }^{14}$ Interpretacja indywidualna Dyrektora Krajowej Informacji Skarbowej z 19 grudnia 2017 r., nr 0115-KDIT3.4011.352.2017.1.PSZ; interpretacja indywidualna Dyrektora Krajowej Informacji Skarbowej z 13 marca 2018 r., nr 0115-KDIT3.4011.32.2018.1.MPŁ. 
jeżeli wierzytelności te zostały spłacone na rzecz otrzymującego je wspólnika. Powołane przepisy rozszerzają kategorię środków pieniężnych, a jednocześnie ograniczają zakres zastosowania art. 14 ust. 3 pkt 12 lit. b u.p.d.o.f. oraz art. 12 ust. 4 pkt 3b u.p.d.o.p. o określone kategorie wierzytelności.

Stosownie do powyższego przypadku, gdy występujący wspólnik otrzyma tytułem wynagrodzenia składniki majątku niespełniające na gruncie ustaw o podatkach dochodowych definicji środków pieniężnych, nie dojdzie po jego stronie do powstania przychodu do opodatkowania w momencie otrzymania tych składników majątku. Niemniej, stosownie do dalszego brzmienia art. 14 ust. 2 pkt 17 lit. b u.p.d.o.f. oraz art. 12 ust. 4 pkt 3 b u.p.d.o.p., moment opodatkowania podatkiem dochodowym po stronie występującego wspólnika został odroczony do chwili odpłatnego zbycia składników majątku otrzymanych tytułem wynagrodzenia za wystąpienie ze spółki niebędącej osobą prawną.

W przypadku, gdy występującym wspólnikiem był podatnik podatku dochodowego od osób prawnych, opodatkowanie podatkiem dochodowym następować będzie w każdym przypadku odpłatnego zbycia otrzymanych uprzednio składników majątku lub otrzymania spłaty wierzytelności niewypełniającej definicji środków pieniężnych, o których mowa w art. 12 ust. $4 \mathrm{~g}$ u.p.d.o.p. $\mathrm{W}$ takiej sytuacji, w przypadku odpłatnego zbycia składników majątku przychodem będzie ich wartość wyrażona w cenie, za którą są zbywane. Cena ta powinna jednocześnie odpowiadać warunkom rynkowym, bowiem przy obliczaniu przychodu powstaje obowiązek odpowiedniego zastosowania art. 14 ust. 1-3 u.p.d.o.p. Jeżeli natomiast wspólnik otrzymał spłatę wierzytelności innej niż wierzytelność wypełniająca definicję środków pieniężnych, o których mowa $\mathrm{w}$ art. 12 ust. $4 \mathrm{~g}$ u.p.d.o.p., przychodem do opodatkowania podatkiem dochodowym będzie przychód uzyskany przez wspólnika z tej spłaty. Podatnik będzie miał również prawo do pomniejszenia powstałego w opisany powyżej sposób przychodu o koszty jego uzyskania. Stosownie do treści art. 16 ust. 1 pkt 8 f u.p.d.o.p., w przypadku odpłatnego zbycia składników majątku otrzymanych w związku z wystąpieniem ze spółki niebędącej osobą prawną, do kosztów uzyskania przychodów możliwe jest zaliczenie wydatków na nabycie lub wytworzenie tych składników majątku, pod warunkiem, że uprzednio nie zostały one zaliczone do kosztów uzyskania przychodów w jakiejkolwiek formie. Jednocześnie, odpowiednie zastosowanie $\mathrm{w}$ takim przypadku znajduje art. 15 ust. 1t u.p.d.o.p., stosownie do którego „w przypadku odpłatnego zbycia przez spółkę niebędącą osobą prawną rzeczy i praw będących przedmiotem wkładu do takiej spółki, za koszt uzyskania przychodu uważa się: 
1) wartość początkową przyjętą przez spółkę w ewidencji środków trwałych oraz wartości niematerialnych i prawnych, ustaloną zgodnie $\mathrm{z}$ art. $16 \mathrm{~g}$ ust. 1 pkt $4 \mathrm{a}$, pomniejszoną o sumę odpisów amortyzacyjnych - jeżeli rzeczy te lub prawa były zaliczone do środków trwałych lub wartości niematerialnych i prawnych spółki;

2) wartość poniesionych wydatków na nabycie albo wytworzenie przedmiotu wkładu, niezaliczonych do kosztów uzyskania przychodów w jakiejkolwiek formie - jeżeli rzeczy te lub prawa nie były zaliczone do środków trwałych lub wartości niematerialnych i prawnych spółki”.

W razie, gdy występujący wspólnik był podatnikiem podatku dochodowego od osób fizycznych, stosownie do treści art. 14 ust. 3 pkt 12 lit. b u.p.d.o.f., odpłatne zbycie składników majątku otrzymanych tytułem wystąpienia ze spółki niebędącej osobą prawną (w tym spłata otrzymanych tytułem wystąpienia wierzytelności niewchodzących w zakres środków pieniężnych, o których mowa w art. 14 ust. 8 u.p.d.o.f.) spowoduje powstanie przychodu po stronie zbywającego, chyba że zostaną spełnione przesłanki, o których mowa w dalszej części art. 14 ust. 3 pkt 12 lit. b u.p.d.o.f. Stosownie do powołanego przepisu, do przychodów nie zalicza się przychodów z odpłatnego zbycia składników majątku otrzymanych w związku z wystąpieniem ze spółki niebędącej osobą prawną, jeżeli od pierwszego dnia miesiąca następującego po miesiącu, w którym nastąpiło wystąpienie wspólnika z takiej spółki, do dnia ich odpłatnego zbycia upłynęło sześć lat i odpłatne zbycie nie następuje w wykonaniu działalności gospodarczej lub działów specjalnych produkcji rolnej. Jeżeli przesłanki powyższe nie zostaną spełnione, podatnik osiągnie przychód z pozarolniczej działalności gospodarczej, o której mowa w art. 10 ust. 1 pkt 3 u.p.d.o.f. ${ }^{15}$, oraz, zgodnie $\mathrm{z}$ art. 24 ust. 3 d u.p.d.o.f., dochodem będzie różnica między przychodem uzyskanym z odpłatnego zbycia a wydatkami poniesionymi na nabycie lub wytworzenie, niezaliczonymi w jakiejkolwiek formie do kosztów uzyskania przychodów przez wspólnika lub spółkę. Odpowiednie zastosowanie w tym przypadku znajdzie art. 22 ust. 8a u.p.d.o.f., zgodnie z którym „w przypadku odpłatnego zbycia przez spółkę niebędącą osobą prawną rzeczy i praw będących przedmiotem wkładu do takiej spółki, za koszt uzyskania przychodu uważa się:

1) wartość początkową przyjętą przez spółkę w ewidencji środków trwałych oraz wartości niematerialnych i prawnych, ustaloną zgodnie

${ }^{15}$ Por. wyrok Naczelnego Sądu Administracyjnego z 1 czerwca 2016 r., sygn. II FSK $1584 / 14$. 
$\mathrm{z}$ art. $22 \mathrm{~g}$ ust. 1 pkt 4, pomniejszoną o sumę odpisów amortyzacyjnych - jeżeli rzeczy te lub prawa były zaliczone do środków trwałych lub wartości niematerialnych i prawnych spółki;

2) wartość poniesionych wydatków na nabycie albo wytworzenie przedmiotu wkładu, niezaliczonych do kosztów uzyskania przychodów w jakiejkolwiek formie - jeżeli rzeczy te lub prawa nie były zaliczone do środków trwałych lub wartości niematerialnych i prawnych spółki”.

Odpowiednie zastosowanie art. 22 ust. 8a u.p.d.o.f. oznacza, że zasady wynikające ze wskazanego przepisu znajdą zastosowanie niezależnie od tego, czy odpłatne zbycie przez byłego wspólnika następuje w wykonaniu działalności gospodarczej. Jednocześnie, jeżeli w momencie zbycia składników majątku otrzymanych tytułem wynagrodzenia za wystąpienie ze spółki niebędącej osobą prawną podatnik nie był opodatkowany tzw. stawką liniową, zobowiązany będzie do obliczenia podatku według skali podatkowej, o której mowa w art. 27 u.p.d.o.f. Bez znaczenia pozostaje, czy w momencie otrzymania tych składników majątku od spółki zastosowanie do niego znajdowała tzw. stawka liniowa ${ }^{16}$.

Jeżeli występujący wspólnik otrzymał tytułem wynagrodzenia środki trwałe lub wartości niematerialne i prawne, ma on prawo do wprowadzenia ich do prowadzonej przez siebie ewidencji środków trwałych oraz wartości niematerialnych i prawnych oraz amortyzacji. Stosownie do brzmienia art. 22g ust. 14c w zw. z art. 22g ust. 12 u.p.d.o.f., wartość początkową środków trwałych oraz wartości niematerialnych i prawnych ustala się w wysokości wartości początkowej określonej w ewidencji spółki niebędącej osobą prawną, z której wspólnik występuje. Jednocześnie, zgodnie $\mathrm{z}$ art. $22 \mathrm{~h}$ ust. 3c w zw. z art. 22h ust. 3 u.p.d.o.f., występujący wspólnik zobowiązany jest do dokonywania odpisów amortyzacyjnych z uwzględnieniem dotychczasowej wysokości odpisów oraz do kontynuacji metody amortyzacji przyjętej przez spółkę niebędącą osobą prawną. Takie same zasady, stosownie do treści art. $16 \mathrm{~g}$ ust. 10c w zw. $\mathrm{z}$ art. $16 \mathrm{~g}$ ust. 9 u.p.d.o.p. oraz art. 16 h ust. $3 \mathrm{c} \mathrm{w}$ zw. $\mathrm{z}$ art. 16 h ust. 3 u.p.d.o.p., znajdują zastosowanie w przypadku otrzymania środków trwałych lub wartości niematerialnych i prawnych tytułem wynagrodzenia za wystąpienie ze spółki niebędącej osobą prawną przez wspólnika będącego podatnikiem podatku dochodowego od osób prawnych.

${ }^{16}$ Por.: interpretacja indywidualna Dyrektora Krajowej Informacji Skarbowej z 19 kwietnia 2017 r., nr 3063-ILPB1-3.4511.81.2017.1.MC. 
Zgodnie z aktualnym stanowiskiem organów podatkowych, wyrażanym $\mathrm{w}$ wydawanych interpretacjach indywidualnych ${ }^{17}$, wypłata wynagrodzenia $\mathrm{w}$ formie niepieniężnej wspólnikowi z tytułu jego wystąpienia ze spółki niebędącej osobą prawną może prowadzić do powstania obowiąz$\mathrm{ku}$ podatkowego na gruncie art. 14 ust. $2 \mathrm{f} \mathrm{w} \mathrm{zw.} \mathrm{z}$ art. 14 ust. 2e u.p.d.o.f. oraz art. 14a u.p.d.o.p. po stronie pozostałych wspólników spółki niebędącej osobą prawną. Stosownie do powołanych przepisów, jeżeli spółka niebędąca osobą prawną poprzez wykonanie świadczenia niepieniężnego reguluje w całości lub w części zobowiązanie, przychodem jest wysokość zobowiązania uregulowanego w następstwie takiego świadczenia. Jeśli jednak wartość rynkowa świadczenia niepieniężnego jest wyższa od wysokości uregulowanego zobowiązania, to przychodem jest wartość rynkowa świadczenia niepieniężnego, np. wydawanej nieruchomości. Przychód danego wspólnika określany jest proporcjonalnie do posiadanego przez niego udziału w zysku, stosownie do zasad wynikających $\mathrm{z}$ art. 8 u.p.d.o.f. lub art. 5 u.p.d.o.p. Stanowisko to znalazło potwierdzenie w nieprawomocnych orzeczeniach wojewódzkich sądów administracyjnych ${ }^{18}$. Jednocześnie, stosownie do powołanych powyżej interpretacji indywidualnych wydanych przez organy podatkowe, możliwe jest rozpoznanie kosztów uzyskania przychodów według zasad właściwych dla odpłatnego zbycia składników majątku wydawanych w zamian za wykonanie ciążącego na spółce zobowiązania. Przykładowo, w przypadku przekazania na rzecz występującego wspólnika środków trwałych lub wartości niematerialnych i prawnych, kosztem uzyskania przychodów będzie, proporcjonalnie do udziału w zysku przysługującego wspólnikowi osiągającemu przychód, wartość początkowa określona w ewidencji środków trwałych oraz wartości niematerialnych i prawnych spółki niebędącej osobą prawną, pomniejszona o dokonane odpisy amortyzacyjne.

${ }^{17}$ Por.: interpretacja indywidualna Dyrektora Krajowej Informacji Skarbowej z 11 stycznia 2018 r., nr 0115-KDIT3.4011.366.2017.1.MPŁ; interpretacja indywidualna Dyrektora Krajowej Informacji Skarbowej z 9 marca 2018 r., nr 0114-KDIP2-3.4010.344.2017.2.MS.

${ }^{18}$ Wyrok Wojewódzkiego Sądu Administracyjnego w Warszawie z 10 stycznia 2018 r., sygn. III SA/Wa 385/17 [nieprawomocny]; wyrok Wojewódzkiego Sądu Administracyjnego w Gliwicach z 18 maja 2016 r., sygn. I SA/Gl 1264/15 [nieprawomocny]. 
3. WYSTĄPIENIE ZA WYNAGRODZENIEM W FORMIE RZECZOWEJ - SKUTKI NA GRUNCIE PODATKU OD TOWARÓW I USŁUG

Przekazanie składników majątku występującemu wspólnikowi tytułem wynagrodzenia za wystąpienie ze spółki niebędącej osobą prawną może prowadzić do powstania obowiązku podatkowego w podatku od towarów i usług. Jeżeli składniki majątku przekazywane tytułem wynagrodzenia za wystąpienie ze spółki stanowią przedsiębiorstwo lub zorganizowaną część przedsiębiorstwa, której definicja zawarta jest w treści art. 2 pkt 27e ustawy z dnia 11 marca 2004 r. o podatku od towarów i usług ${ }^{19}$, opisywana czynność wyłączona będzie z opodatkowania podatkiem od towarów i usług na podstawie art. 6 pkt 1 u.p.t.u. W odniesieniu natomiast do przekazania składników majątku niestanowiących przedsiębiorstwa czy zorganizowanej części przedsiębiorstwa, rozważenia wymaga, na jakiej podstawie opisywana czynność podlegać może opodatkowaniu podatkiem od towarów i usług.

$\mathrm{W}$ jednej $\mathrm{z}$ interpretacji indywidualnych ${ }^{20}$ organ podatkowy uznał przekazanie przez spółkę występującemu wspólnikowi składników niepieniężnych za odpłatną dostawę towarów, o której mowa w art. 7 ust. 1 u.p.t.u. $\mathrm{Z}$ kolei w innej interpretacji indywidualnej ${ }^{21}$ podobne przekazanie składników niepieniężnych tytułem wynagrodzenia za wystąpienie ze spółki osobowej uznane zostało za nieodpłatne przekazanie towarów, o którym mowa w art. 7 ust. 2 u.p.t.u., podlegające opodatkowaniu podatkiem od towarów i usług. Wynagrodzenie za wystąpienie wspólnika stanowiło bowiem spłatę przysługującego mu zysku, który uprzednio został pozostawiony w spółce i przekazany na kapitał zapasowy. Właściwa kwalifikacja opisywanych czynności jest o tyle istotna, że w przypadku uznania ich za nieodpłatne przekazanie towarów, o którym mowa w art. 7 ust. 2 u.p.t.u., opodatkowanie następuje wyłącznie, jeżeli podatnikowi (przekazującej spółce) przysługiwało, w całości lub w części, prawo do obniżenia kwoty podatku należnego o kwotę podatku naliczonego z tytułu nabycia, importu lub wytworzenia przekazywanych towarów lub ich części składowych. Biorąc pod uwagę fakt, że w związku z przekazaniem środków niepieniężnych

${ }^{19}$ Ustawa z dnia 11 marca 2004 r. o podatku od towarów i usług, Dz.U. z 2017 r., poz. 1221 ze zm.; dalej: u.p.t.u.

${ }^{20}$ Interpretacja indywidualna Dyrektora Izby Skarbowej w Łodzi z 19 lipca 2013 r., nr IPTPP2/443-337/13-4/JN.

${ }^{21}$ Interpretacja indywidualna Dyrektora Krajowej Informacji Skarbowej z 26 czerwca 2017 r., nr 0113-KDIPT1-1.4012.124.2017.3.ŻR. 
występującemu wspólnikowi spółka wykonuje jedynie nałożone na nią zobowiązanie, nie otrzymując nic w zamian, należy przychylić się do stanowiska organu podatkowego wyrażonego w drugiej z powołanych powyżej interpretacji, że czynność taka stanowi nieodpłatne przekazanie towarów, o którym mowa w art. 7 ust. 2 u.p.t.u. Niezależnie od kwalifikacji dokonywanych czynności, jako opodatkowanych na podstawie art. 7 ust. 1 u.p.t.u. lub art. 7 ust. 2 u.p.t.u., w każdym wypadku konieczne jest przeprowadzenie analizy, czy dokonywana czynność wypełnia przesłanki do zastosowania jednego ze zwolnień, o których mowa w art. 43 u.p.t.u.

Jednocześnie, jeżeli występujący wspólnik otrzymuje z tytułu wynagrodzenia za wystąpienie ze spółki środki trwałe lub wartości niematerialne o wartości początkowej przekraczającej 15 tys. PLN i przekazanie to nie podlega opodatkowaniu podatkiem od towarów i usług ( $\mathrm{z}$ uwagi na zastosowanie zwolnienia $\mathrm{z}$ opodatkowania lub niepodleganie podatkowi od towarów i usług), każdorazowo należy pamiętać o obowiązku dokonania korekty, o której mowa w art. 91 u.p.t.u. Obowiązek opisywanej powyżej korekty podatku naliczonego powstaje, jeżeli przy nabyciu lub wytworzeniu podatnik (spółka) dokonał obniżenia podatku należnego o kwotę podatku naliczonego od przekazywanych składników majątku, a przekazanie zostało dokonane w ciągu 10 lat (w odniesieniu do nieruchomości oraz praw użytkowania wieczystego) lub 5 lat (w odniesieniu do pozostałych środków trwałych lub wartości niematerialnych i prawnych), licząc od roku, w którym dany składnik majątku został oddany do używania przez spółkę. Podkreślić w tym miejscu należy, że nie powstaje on w sytuacji, gdy składniki majątku przekazywane tytułem wynagrodzenia za wystąpienie ze spółki stanowią przedsiębiorstwo lub zorganizowaną część przedsiębiorstwa. Stosownie bowiem do treści art. 91 ust. 9 u.p.t.u. „w przypadku transakcji zbycia przedsiębiorstwa lub zorganizowanej części przedsiębiorstwa korekta określona w ust. 1-8 jest dokonywana przez nabywcę przedsiębiorstwa lub nabywcę zorganizowanej części przedsiębiorstwa”.

\section{WYSTĄPIENIE WSPÓLNIKA BEZ WYNAGRODZENIA}

Jak wskazano powyżej, przepisy Kodeksu spółek handlowych dopuszczają ustalenie innych niż kodeksowe zasad określenia wynagrodzenia należnego wspólnikowi z tytułu złożenia przez niego oświadczenia o wypowiedzeniu umowy spółki, a nawet dopuszczają wyłączenie prawa do wynagrodzenia należnego występującemu wspólnikowi. Pomimo braku 
faktycznego przepływu środków czynność wystąpienia wspólnika ze spółki, z jednoczesnym pozostawieniem w spółce należnego występującemu wspólnikowi zysku oraz brakiem zwrotu wniesionego przez niego wkładu, wymaga rozważenia pod kątem wystąpienia ewentualnych skutków na gruncie ustaw o podatkach dochodowych.

W pierwszej kolejności wskazać należy, że wystąpienie wspólnika ze spółki niebędącej osobą prawną bez przyznania mu wynagrodzenia $\mathrm{z}$ tytułu wystąpienia nie powoduje powstania przychodu po stronie samej spółki czy też pozostałych wspólników. Stanowisko takie potwierdzane jest przez organy podatkowe w wydawanych interpretacjach indywidualnych ${ }^{22}$. Ewentualny przychód po stronie pozostałych wspólników może powstać w przypadku późniejszego odpłatnego zbycia przysługującego im ogółu praw i obowiązków w spółce lub też złożenia oświadczenia o wypowiedzeniu umowy spółki. Brak wypłaty wynagrodzenia jednemu ze wspólników w związku z jego wystąpieniem ze spółki wpływa bowiem na zwiększenie majątku spółki oraz udziału kapitałowego przysługującego pozostałym wspólnikom, a tym samym na wartość zbywanego ogółu praw i obowiązków czy wysokość przysługującego wynagrodzenia za wystąpienie ze spółki²3.

Wystąpienie wspólnika ze spółki bez wynagrodzenia oznaczać może również pozostawienie w spółce przysługującego mu zysku za poprzednie lata obrotowe, w tym za rok obrotowy, w którym nastąpiło wystąpienie ze spółki. Zysk ten mógł bowiem zostać przeznaczony np. na finansowanie bieżącej działalności spółki. Czynność ta nie podlega jednakże opodatkowaniu podatkiem od czynności cywilnoprawnych, w szczególności jako podwyższenie wkładu wspólników ${ }^{24}$ czy pożyczka udzielona spółce ${ }^{25}$.

${ }^{22}$ Interpretacja indywidualna Dyrektora Krajowej Informacji Skarbowej z 23 lutego 2018 r., nr IPPB1/4511-469/16-4/S/KS; interpretacja indywidualna Dyrektora Krajowej Informacji Skarbowej z 10 maja 2017 r., nr 0112-KDIL3-3.4011.28.2017.1.AK; interpretacja indywidualna Dyrektora Krajowej Informacji Skarbowej z 22 lutego 2017 r., nr 0461-ITP B1.4511.32.2017.1.PSZ; interpretacja indywidualna Dyrektora Izby Skarbowej w Poznaniu z 25 maja 2016 r., nr ILPB1/4511-1-328/16-2/KS; interpretacja indywidualna Dyrektora Izby Skarbowej w Warszawie z 8 stycznia 2015 r., nr IPPB1/415-1141/14-5/MS1.

${ }^{23}$ Por. wyrok Naczelnego Sądu Administracyjnego z 19 czerwca 2012 r., sygn. II FSK 891/11; wyrok Naczelnego Sądu Administracyjnego z 16 maja 2012 r., sygn. II FSK 2072/10; wyrok Wojewódzkiego Sądu Administracyjnego w Warszawie z 14 września 2017 r., sygn. III SA/Wa 2905/16 [prawomocny]; wyrok Wojewódzkiego Sądu Administracyjnego w Warszawie z 6 kwietnia 2016 r., sygn. III SA/Wa 1250/15 [nieprawomocny].

${ }^{24}$ Wyrok Naczelnego Sądu Administracyjnego z 10 listopada 2016 r., sygn. II FSK 2834/14.

${ }^{25}$ Interpretacja indywidualna Dyrektora Krajowej Informacji Skarbowej z 7 listopada 2017 r., nr 0111-KDIB4.4014.286.2017.1.JKU; interpretacja indywidualna Dyrektora Izby 
Niemniej jeżeli zysk pozostawiony w spółce, a przysługujący wspólnikowi, który wystąpił ze spółki, zostanie następnie wypłacony pozostałym wspólnikom, konieczne jest rozważenie, czy zdarzenie to nie wywołuje skutków podatkowych w podatku dochodowym po stronie wspólników, którzy otrzymali zysk przysługujący uprzednio byłemu wspólnikowi. Jeżeli pozostającym w spółce wspólnikom wypłacono zysk za rok obrotowy, w którym nastąpiło wystąpienie byłego wspólnika ze spółki, wypłata ta pozostaje neutralna podatkowo. W razie wystąpienia jednego ze wspólników przypadający mu udział w zysku zostaje przydzielony pozostającym w spółce wspólnikom. Tym samym, jeżeli wystąpienie wspólnika następuje w trakcie roku podatkowego wspólników i roku obrotowego spółki, dochód osiągany za pośrednictwem spółki niebędącej osobą prawną pozostaje w dalszym ciągu opodatkowywany, lecz tylko przez wspólników pozostających w spółce, z wyłączeniem wspólnika, który ze spółki wystąpił. Zysk wynikający ze sprawozdania finansowego spółki, wypłacany wspólnikom po zakończeniu jej roku obrotowego, stanowi niejako pochodną dochodu opodatkowanego podatkiem dochodowym przez wspólników w trakcie roku obrotowego ${ }^{26}$.

Przepisy ustaw o podatkach dochodowych nie określają jednoznacznie, jakie skutki podatkowe wiążą się $\mathrm{z}$ wypłatą pozostającym w spółce wspólnikom zysku za poprzednie lata obrotowe, który przysługiwał byłemu wspólnikowi. Skutki podatkowe opisywanych zdarzeń nie znajdują również potwierdzenia $\mathrm{w}$ wydawanych przez organy podatkowe interpretacjach indywidualnych oraz orzeczeniach sądów administracyjnych. Niemniej, stosownie do interpretacji indywidualnej wydanej przez Dyrektora Izby Skarbowej w Bydgoszczy ${ }^{27}$, w przypadku wypłaty wspólnikowi zysku spółki niebędącej osobą prawną za lata obrotowe, w których podmiot ten nie posiadał statusu wspólnika w wypłacającej zysk spółce, wypłata ta powinna zostać opodatkowana podatkiem dochodowym, stanowiąc przychód z praw majątkowych.

Skarbowej w Katowicach z 17 listopada 2016 r., nr 2461-IBPB-2-1.4514.529.2016.2.BJ; interpretacja indywidualna Dyrektora Izby Skarbowej w Katowicach z 28 lipca 2016 r., nr IBPB-2-1/4514-283/16/PM; interpretacja indywidualna Dyrektora Izby Skarbowej w Katowicach z 26 kwietnia 2016 r., nr IBPB-2-1/4514-73/16/DP; interpretacja indywidualna Dyrektora Izby Skarbowej w Warszawie z 2grudnia 2015 r., nr IPPB2/4514-449/15-2/AK.

${ }^{26}$ Por.: interpretacja indywidualna Dyrektora Izby Skarbowej w Łodzi z 24 listopada 2015 r., nr IPTPB1/4511-560/15-3/MH; interpretacja indywidualna Dyrektora Izby Skarbowej w Bydgoszczy z 3 października 2014 r., nr ITPB1/415-772/14/MR.

${ }^{27}$ Interpretacja indywidualna Dyrektora Izby Skarbowej w Bydgoszczy z 22 listopada 2016 r., nr ITPB1/4511-742/16/PSZ. 
Na zakończenie podkreślić należy dodatkowo, że w każdym przypadku wystąpienia wspólnika ze spółki osobowej pozostali wspólnicy powinni dokonać zmiany umowy spółki celem uaktualnienia jej brzmienia do nowego stanu osobowego. W szczególności uaktualniony powinien zostać podział zysków pomiędzy pozostających w spółce wspólników, jeżeli został on ustalony uprzednio w oderwaniu od zasad kodeksowych. Zmiana podziału zysków pomiędzy wspólników w trakcie roku podatkowego wywiera ten skutek, że wpływa na zasady opodatkowania dochodów osiąganych za pośrednictwem spółki niebędącej osobą prawną. Tym samym, jeżeli udział w zysku pozostałych wspólników uległ zmianie w związku z wystąpieniem jednego $\mathrm{z}$ nich ze spółki, to do momentu dokonania zmiany podziału zysków (tj. do momentu wystąpienia wspólnika ze spółki) dochód do opodatkowania przypadający na danego wspólnika powinien być ustalany według dotychczasowych zasad, obowiązujących w okresie przed wystąpieniem wspólnika ze spółki. Po tym zdarzeniu natomiast osiągnięte za pośrednictwem spółki niebędącej osobą prawną dochody, przypadające na pozostających w spółce wspólników, powinny być ustalane według nowych zasad ${ }^{28}$.

Poza powyższym, na spółce ciąży ponadto obowiązek sporządzenia wykazu składników majątku, o którym mowa w art. 24 ust. 3a u.p.d.o.f., na dzień wystąpienia wspólnika ze spółki ${ }^{29}$. Powołany przepis nie zawiera zamkniętej listy danych, jakie powinny zostać uwzględnione w wykazie. Wskazuje natomiast, że powinien on zawierać co najmniej: liczbę porządkową, określenie (nazwę) składnika majątku, datę nabycia składnika majątku, kwotę wydatków poniesionych na nabycie składnika majątku oraz kwotę wydatków poniesionych na nabycie składnika majątku zaliczoną do kosztów uzyskania przychodów, wartość początkową, metodę amortyzacji, sumę odpisów amortyzacyjnych oraz wysokość wypłaconych środków pieniężnych należnych wspólnikom z tytułu udziału w spółce niebędącej osobą prawną na dzień wystąpienia lub likwidacji.

Powyższe rozważania prowadzą do wniosku, że czynność wystąpienia wspólnika ze spółki pociąga za sobą daleko idące konsekwencje nie tylko

${ }^{28}$ Por.: interpretacja indywidualna Dyrektora Izby Skarbowej w Bydgoszczy z 23 czerwca 2015 r., nr ITPB1/4511-540/15/MR; interpretacja indywidualna Dyrektora Izby Skarbowej w Łodzi z 24 listopada 2015 r., nr IPTPB1/4511-560/15-3/MH

${ }^{29}$ Wyrok Naczelnego Sądu Administracyjnego z 29 listopada 2016 r., sygn. II FSK 2827/14. 
w zakresie prawa handlowego, ale w szczególności wywołuje istotne skutki na gruncie ustaw podatkowych po stronie występującego wspólnika, jak i wspólników pozostających w spółce. Pomimo uregulowania zasad opodatkowania wynagrodzenia otrzymywanego przez występującego wspólnika, przepisy dotyczące tego zdarzenia pozostawiają $\mathrm{w}$ dalszym ciągu wiele wątpliwości, które mogą zostać rozstrzygnięte jedynie w drodze dalszej wykładni. W szczególności niejasne pozostają zasady opodatkowania wypłaty zysku, którego zrzekł się występujący wspólnik, a który następnie został wypłacony pozostającym w spółce wspólnikom. Wątpliwości budzi również kwestia zysku ze spraw niezakończonych, wypłaconego byłemu wspólnikowi już po jego wystąpieniu ze spółki. Stosownie bowiem do stanowiska organów podatkowych, wyrażonego w jednej z interpretacji indywidualnych ${ }^{30}$, zysk taki powinien zostać uprzednio opodatkowany na zasadach ogólnych przez wspólników pozostających w spółce, stosownie do treści art. 8 u.p.d.o.f. lub art. 5 u.p.d.o.p., a następnie rozliczony z byłym wspólnikiem. Brak natomiast przepisów, które jasno wskazywałyby, wedle jakich zasad kwota tego zysku powinna zostać opodatkowania u byłego wspólnika. Czy powinna zostać uznana za część wynagrodzenia należnego mu z tytułu wystąpienia ze spółki czy też stanowić przychód z kapitałów pieniężnych? Przyjęcie drugiego stanowiska w praktyce oznaczałoby podwójne opodatkowanie tych samych środków - w pierwszej kolejności przez pozostających w spółce wspólników, a następnie przez byłego wspólnika, któremu zysk został wypłacony. Podniesione powyżej wątpliwości rodzą ryzyko potencjalnych sporów z organami podatkowymi, które mogłoby zostać znacząco ograniczone wydaniem interpretacji ogólnej.

\section{BIBLIOGRAFIA}

Rodzynkiewicz M., Kodeks spółek handlowych. Komentarz, wyd. 4, Warszawa 2012.

${ }^{30}$ Interpretacja indywidualna Dyrektora Izby Skarbowej w Poznaniu z 30 czerwca 2016 r., nr ILPB1/4511-1-605/16-2/KF. 


\section{LEGAL AND FISCAL CONSEQUENCES OF A WITHDRAWAL OF A PARTNER} FROM A TAX TRANSPARENT PARTNERSHIP

Summary. The withdrawal of a partner from a tax transparent partnership implies many tax consequences, in particular on the grounds of income tax and value added tax as well. These consequences vary, depending on whether the remuneration received by a withdrawing partner is paid in cash or in subsided form. Moreover, if a withdrawing partner has not received any remuneration such an event causes tax consequences different to those when a withdrawing partner has received a remuneration in which ever form. The complex analysis of the matter in question also requires the determination of tax consequences originated on the side of the remaining partners. The article considers tax consequences of the withdrawal of a partner from a partnership, taking into account the jurisprudence of administrative courts and tax rulings issued by tax authorities.

Keywords: a partnership, a partnership not being a legal entity, withdrawal of a partner, income tax, value added tax, remuneration in non-cash form, participation interest. 